\title{
Beta-Sitosterol with Antimicrobial Property from the Stem Bark of Pomegranate (Punica granatum Linn)
}

\author{
*NWEZE, C; IBRAHIM, H; NDUKWE, GI \\ Department of Chemistry, Ahmadu Bello University, Zaria, Kaduna State, Nigeria \\ *Corresponding Author Email:chimezienwa72@gmail.com; Tel: +2348066365208
}

\begin{abstract}
The aim of this research was to isolate and characterize bioactive substances that may be responsible for the ethno medicinal uses of Punica granatum. Phytochemical constituents and characterization led to the isolation of Beta-Sitosterol from the hexane extract of the stem bark of the plant. The structure of the isolated compound was elucidated by spectra data including FTIR, 1D- and 2D-NMR. The compound was active against Salmonella typhi and Escherichia coli with zones of inhibition of 20 and $35 \mathrm{~mm}$ respectively which were appreciable with that of the standard. The values of minimum inhibitory concentration (MIC) were as low as 6.25 and $12.5 \mu \mathrm{g} / \mathrm{ml}$ against Salmonella typhi and Escherichia coli respectively.
\end{abstract}

DOI: https://dx.doi.org/10.4314/jasem.v23i6.7

Copyright: Copyright $\mathbb{C} 2018$ Nweze et al. This is an open access article distributed under the Creative Commons Attribution License (CCL), which permits unrestricted use, distribution, and reproduction in any medium, provided the original work is properly cited.

Dates: Received: 02 October 2018; Revised: 26 November 2018; Accepted 22 June 2019

Keywords: Punica granatum, Stem Bark, Antimicrobial, Beta-Sitosterol

Plants generally produce chemical compounds as part of their normal metabolic activities. These are arbitrarily divided into primary metabolites such as amino acid and sugar found in all plants and secondary metabolites which are compounds that are not essential for basic functions. The secondary metabolites are found in most plants, and are useful and found only in a particular genus or species (Patrick, 2005). Medicinal plants are plants whose extracts or parts can be used directly or indirectly for the treatment of different ailments. Therefore, the use of traditional medicine and medicinal plants in most developing countries as a basis for the maintenance of good health has been widely observed (Edward, 2001). Scientists throughout the world are trying to explore the precious assets of medicinal plants to help the suffering humanity. Today more than $30 \%$ of the pharmaceutical preparations are based on plants (Shinwari and Khan, 1998). It was observed that developed countries mostly import raw materials of valuable medicinal plants from developing countries. They are then screened, analyzed and used in drug preparations, and returned as high priced medicines to developing countries (Shinawie, 2002). Currently, more than $50 \%$ of drugs in clinical use are of naturalproduct origin, and about half of the world's 25 bestselling pharmaceutical agents are natural-products derived (Jin et al., 2011).The word "drug" comes from the Dutch word "droog" (from the French word Drogue) which means "dried plant". Some examples are insulin from the roots of Dahlias, quinine from the
Cinchona, morphine and codeine from the Poppy. Medicinal plants are plants whose extracts or parts can be used directly or indirectly for the treatment of different ailments. Therefore, the use of traditional medicine and medicinal plants in most developing countries as a basis for the maintenance of good health has been widely observed (Edward, 2001). Scientists throughout the world are trying to explore the precious assets of medicinal plants to help the suffering humanity. The objectives of this research include, collection and identification of the plant material, extraction of the plant material using suitable solvent, purification and isolation of bioactive compounds from the crude hexane extract, antimicrobial activity of the isolated compound and structural elucidation of the isolated compound using IR, 1D and 2D NMR technique

\section{MATERIALS AND METHODS}

Collection of plant material: The plant was collected fresh from Gellesu, Zaria, Nigeria in April, 2016. It was identified at the Biological Science Department, Ahmadu Bello University, Zaria, Nigeria. A voucher specimen number 1351 was deposited in the Herbarium. The stem bark was air dried and pulverized using wooden mortar and pestle. The ground material was keep for further analysis.

Extraction of plant materials: The pulverized plant material $(1 \mathrm{~kg})$ was extracted exhaustively using soxhlet apparatus with methanol as the solvent. The 
extract was filtered and concentrated in vacuo at $40{ }^{\circ} \mathrm{C}$ using a rotary evaporator. The concentrated methanol extract was reconstituted in distilled water and partitioned with hexane, chloroform and ethyl acetate. The resulting fractions were concentrated in vacuo at $40{ }^{0} \mathrm{C}$ using rotary evaporator and later air dried completely (Sofowora, 1993).

Chromatographic Purification of Extracts: A portion of the hexane extract was dissolved in chloroform and the solution was spotted on TLC plates. The TLC plates were developed using the following solvent systems of hexane and ethyl acetate in the ratio of 9:1, $8: 2$ and 7:3 and were viewed individually under UV (356 nm) light and also with vanillin- $\mathrm{H}_{2} \mathrm{SO}_{4}$ reagent (Bhawani et al 2010). Through several pilot experiments, it was found that the constituent of hexane extract was separated by the solvent system of n-Hexane and ethyl acetate in the ratio of $9: 1$. The hexane extract $(8 \mathrm{~g})$, was subjected to column chromatography on a silica gel (60-120 mesh) stationary phase and eluted with the following solvent system; n-hexane (100\%), n-hexane and ethyl acetate in the ratio $(97.5: 2.5)$ and finally with n-hexane and ethyl acetate in the ratio 19:1, this is the solvent system that yielded the isolated compound (GP1).

Media preparation: Muller Hinton and Sabouroud dextrose agar were the media used as the growth media. They were prepared according to the manufacturer's instructions, boiled to dissolution and were sterilized at $121{ }^{\circ} \mathrm{C}$ for 15 minutes. The media were cooled to $45{ }^{\circ} \mathrm{C}$ and $29 \mathrm{ml}$ of the sterilized media were poured into sterilized Petri dishes. The media were then allowed to cool and solidify. The isolated compound (GP1) was weighed and dissolved in Dimethylsulphoxide (DMSO) to obtain homogenous solutions with the following experimental concentrations of $50.00 \mu \mathrm{g} / \mathrm{ml}, 25.00 \mu \mathrm{g} / \mathrm{ml}, 12.50$ $\mu \mathrm{g} / \mathrm{ml}$ and $6.25 \mu \mathrm{g} / \mathrm{ml}$.

Susceptibility Test of Isolated Compound GP1: The media prepared above were inoculated with $0.1 \mathrm{ml}$ standard inoculums of the test organisms. The inoculums were spread evenly over the surface of the medium by the use of a sterile swab. The agar plates were seeded with the test organisms and the sabouroud dextrose agar with the fungi. The inoculated plates were incubated at $37^{\circ} \mathrm{C}$ for $24 \mathrm{hrs}$ for the bacteria and at $25^{\circ} \mathrm{C}$ for 48 hours for the fungi. Standard cork borer of $6 \mathrm{~mm}$ diameter was used to cut 4 well on each inoculated plate well labeled and appropriate concentration of the solution was introduced into each well. The plates were then incubated at $37{ }^{\circ} \mathrm{C}$ for 24 hours for the bacteria and at $25{ }^{\circ} \mathrm{C}$ for 48 hours for the fungi. They were observed after the periods of incubation for zone of inhibition of growth. The zones were measured with a caliper and the values were recorded in millimeters (NCCLS, 2001).

Determination of minimum inhibitory concentrations (MIC) of the extracts: The minimum inhibitory concentrations of the solution were carried out on the test organisms using the broth dilution method. MacFarlands turbidity scale number 0.5 was prepared to give turbid solution. Normal saline was prepared and was dispensed into test tubes and the microorganisms were then inoculated and incubated at $37{ }^{\circ} \mathrm{C}$ for 24 hours. Dilution of the test microorganisms in the normal saline was performed until the turbidity test that matched that of the Mac-Farlands scale by visual comparison. At this point the microorganisms had a concentration of about $1.5 \times 10^{8} \mathrm{cfu} / \mathrm{ml}$. Having obtained the different concentrations of the GP1 solution in the broth, $0.1 \mathrm{ml}$ of the standard inoculums of the test microorganism in the normal saline were then inoculated in to the test tubes with different concentrations. Incubation was made at $37^{\circ} \mathrm{C}$ for 24 hrs after which each broth was observed for turbidity. The test tubes which showed no turbidity was recorded as the Minimum Inhibition Concentration (MIC) (Tijjani et al., 2011).

Minimum Bactericidal Concentration/ Minimum
Fungicidal Concentration: The Minimum Bactericidal Concentration/minimum Fungicidal Concentrations (MBC/MFC) were carried out to determine if the test microbes were killed or only their growth was inhibited. Mueller-Hinton agar was prepared and sterilized at $121{ }^{0} \mathrm{C}$ for 15 minutes, poured into Petri dishes and were allowed to cool and solidify. The content of the MIC in the serial dilution was sub - cultured into the prepared medium and incubation was done at $37{ }^{\circ} \mathrm{C}$ for $24 \mathrm{~h}$. Thereafter each plate of the medium was observed for colony growth. The value obtained in the plate with lowest concentration of the extracts without colony growth was recorded as the MBC/MFC (NCCLS, 2002).

\section{RESULTS AND DISCUSSION}

The FTIR spectrum of the compound showed absorption bands $\left(\mathrm{cm}^{-1}\right)$ for $\mathrm{OH}$ at 3338.0, $\mathrm{CH}_{3}$ at 2928.0 and $\mathrm{CH}_{2}$ at 2855.1, unconjugated olefinic $(\mathrm{C}=\mathrm{C})$ at $1710.8 \mathrm{~cm}^{-1}$, cyclic methylene groups $\left(\mathrm{CH}_{2}\right)$ at $1461.1 \mathrm{~cm}^{-1}$, gem-dimethyl $\left(-\mathrm{CH}\left(\mathrm{CH}_{3}\right)_{2}\right)$ group at $1379.1 \mathrm{~cm}^{-1}$ and $\mathrm{C}-\mathrm{OH}$ of secondary alcohol at 1058.6 $\mathrm{cm}^{-1}$. This corresponds to what was recorded in literature by Ododo et al (2016). The integration of ${ }^{1} \mathrm{H}$ NMR spectrum showed the presence of fifty hydrogen atoms: six $\mathrm{CH}_{3}$, eleven $\mathrm{CH}_{2}$, nine $\mathrm{CH}$ and one $\mathrm{OH}$ groups. The appearance of the singlets at $\delta 0.66 \mathrm{ppm}$ and $1.03 \mathrm{ppm}$ confirming the presence of two $\mathrm{CH}_{3}$ 
attached to quaternary carbons. The appearance of the complex multiplets at $\delta 2.29 \mathrm{ppm}$ and $2.32 \mathrm{ppm}$ revealed that the two $\mathrm{CH}_{2}$ adjacent to carbon attached to $\mathrm{OH}$ group. The multiplet at $\delta 3.54 \mathrm{ppm}$ is usually due to a proton connected to the carbon which is attached with $\mathrm{OH}$ group. The overlapping triplet signal also appeared for $\mathrm{CH}$ at $\delta 5.37$ indicated the presence of one olefinic proton (Table 1 and fig 3. the 13C NMR spectrum exhibited the existence of 29 carbons. The carbons could be classified as representing $\mathrm{CH}_{3}, \mathrm{CH}_{2}$, $\mathrm{CH}$ or quaternary carbon (quartenary $\mathrm{C}$ ) by DEPT135. The DEPT-135 spectrum indicated the presence of 26 carbons: six peaks appeared up due $\mathrm{CH}_{3}$ groups, nine peaks up for $\mathrm{CH}$ groups and peaks appeared down indicated the presence of eleven $\mathrm{CH}_{2}$ groups (Table 1). The absence of three signals in the DEPT-135 spectrum confirmed the presence of three quaternary carbon atoms (Ododo et al., 2016).In ${ }^{13} \mathrm{C}$ NMR spectrum, the recognizable signals at $140.71 \mathrm{ppm}$ and $121.73 \mathrm{ppm}$ are assignable to the double bond between carbon atoms in position 5 and 6 (C5 = C6), respectively. The signal at $\delta 71.8 \mathrm{ppm}$ is assignable to the $\mathrm{C} 3$ bearing the $\mathrm{OH}$ group, and the signals at $\delta 11.84$ ppm and $19.38 \mathrm{ppm}$ are assignable to the methyl carbons of $\mathrm{C} 19$ and $\mathrm{C} 18$ respectively. The chemical shift value for $\mathrm{C} 18$ is lower due to $\gamma$-gauche interaction that increases the screening of the $\mathrm{C} 18$. However, the loss of $\mathrm{H}$-atom in $\mathrm{C} 6$ results in decrease in screening of the $\mathrm{C} 19$ leading to increase in ${ }^{13} \mathrm{C}$ NMR chemicals shift to higher frequency as reported in literature by Pateh et al (2009). The observed chemical shift values (Table 1) in NMR spectra are very close to values reported NMR Data in the literature for $\beta$-sitosterol (Patra et al., 2010). Based on ${ }^{1} \mathrm{H}$ NMR, ${ }^{13} \mathrm{C}$ NMR, DEPT-135 the molecular formula of the isolated compound was determined to be $\mathrm{C}_{29} \mathrm{H}_{50} \mathrm{O}$. Since the isolated compound gave positive test for steroids, the isolated substances was found to be a $\beta$-sitosterol base on comparative spectral consideration.

Table 1: ${ }^{1} \mathrm{H}$ and ${ }^{13} \mathrm{C}$ NMR chemical shift values for isolated compound and reference signals from original source recorded by $(400 \mathrm{MHz})$ NMR using $\mathrm{CDCl}_{3}$ as solvent

\begin{tabular}{|c|c|c|c|c|c|}
\hline $\begin{array}{l}\text { Carbon } \\
\text { atom }\end{array}$ & $\begin{array}{l}{ }^{13} \mathrm{C} \quad \mathrm{NMR} \\
\text { Experimental }\end{array}$ & $\begin{array}{l}{ }^{13} \mathrm{C} \text { NMR } \\
\text { Literature }\end{array}$ & $\begin{array}{l}{ }^{1} \mathrm{H} \quad \mathrm{NMR} \\
\text { Experimental }\end{array}$ & $\begin{array}{l}{ }^{1} \mathrm{H} \text { NMR } \\
\text { Literature }\end{array}$ & $\begin{array}{l}\text { Nature } \\
\text { of } \\
\text { Carbon }\end{array}$ \\
\hline C-1 & 37.21 & 37.28 & 1.47 & 1.46 & $\mathrm{CH}_{2}$ \\
\hline $\mathrm{C}-2$ & 31.61 & 31.69 & 1.57 & 1.56 & $\mathrm{CH}_{2}$ \\
\hline C-3 & 71.81 & 71.82 & 3.51 & 3.54 & $\mathrm{CH}$ \\
\hline C-4 & 42.29 & 42.33 & 2.32 & 2.32 & $\mathrm{CH}_{2}$ \\
\hline C-5 & 140.71 & 140.77 & -- & -- & $\mathrm{C}$ \\
\hline C-6 & 121.73 & 121.73 & 5.34 & 5.37 & $\mathrm{CH}$ \\
\hline C-7 & 31.91 & 31.93 & 2.01 & 2.04 & $\mathrm{CH}_{2}$ \\
\hline C-8 & 31.89 & 31.93 & 1.67 & 1.69 & $\mathrm{CH}$ \\
\hline C-9 & 50.08 & 50.16 & 1.52 & 1.55 & $\mathrm{CH}_{2}$ \\
\hline$C-10$ & 36.48 & 36.51 & - & - & $\mathrm{C}$ \\
\hline C-11 & 21.05 & 21.11 & 1.50 & 1.52 & $\mathrm{CH}_{2}$ \\
\hline$C-12$ & 39.73 & 39.80 & 1.49 & 1.51 & $\mathrm{CH}_{2}$ \\
\hline$C-13$ & 42.25 & 42.34 & - & - & $\mathrm{C}$ \\
\hline C-14 & 56.72 & 56.76 & 1.50 & 1.50 & $\mathrm{CH}$ \\
\hline$C-15$ & 24.28 & 24.33 & 1.59 & 1.58 & $\mathrm{CH}_{2}$ \\
\hline C-16 & 28.23 & 28.27 & 1.93 & 1.85 & $\mathrm{CH}_{2}$ \\
\hline C-17 & 55.99 & 56.87 & 1.47 & 1.45 & $\mathrm{CH}$ \\
\hline C-18 & 11.84 & 11.89 & 0.66 & 0.70 & $\mathrm{CH}_{3}$ \\
\hline C-19 & 19.38 & 19.42 & 1.03 & 1.03 & $\mathrm{CH}_{3}$ \\
\hline $\mathrm{C}-20$ & 36.12 & 36.17 & 1.61 & 1.60 & $\mathrm{CH}$ \\
\hline C-21 & 18.75 & 18.84 & 0.94 & 0.94 & $\mathrm{CH}_{3}$ \\
\hline $\mathrm{C}-22$ & 33.90 & 33.98 & 0.93 & 0.93 & $\mathrm{CH}_{2}$ \\
\hline $\mathrm{C}-23$ & 25.99 & 26.11 & 1.15 & 1.15 & $\mathrm{CH}_{2}$ \\
\hline C-24 & 45.78 & 45.86 & 1.38 & 1.38 & $\mathrm{CH}$ \\
\hline $\mathrm{C}-25$ & 29.08 & 29.19 & 1.64 & 1.57 & $\mathrm{CH}$ \\
\hline $\mathrm{C}-26$ & 19.81 & 19.84 & 0.84 & .084 & $\mathrm{CH}_{2}$ \\
\hline $\mathrm{C}-27$ & 18.99 & 19.06 & 0.62 & 1.09 & $\mathrm{CH}_{3}$ \\
\hline C-28 & 23.02 & 23.10 & 1.09 & 1.10 & $\mathrm{CH}_{2}$ \\
\hline C-29 & 11.96 & 12.01 & 0.83 & 0.82 & $\mathrm{CH}_{3}$ \\
\hline
\end{tabular}


Table 2: Diameter of Zone of inhibition $(\mathrm{mm})$ and Minimum inhibition concentrate and minimum bactericidal concentration $(\mu \mathrm{g} / \mathrm{ml})$ of

\begin{tabular}{llllllll}
\multicolumn{7}{c}{$\mathrm{GP} 1$} \\
\hline Test organism & \multicolumn{1}{c}{ Diameter of Zone of inhibition $(\mathrm{mm})$} & Ciprofloxacin & MIC $(\mu \mathrm{g} / \mathrm{ml})$ & $\begin{array}{l}\text { MBC } \\
(\mu \mathrm{g} / \mathrm{ml})\end{array}$ \\
\hline & 6.25 & 12.50 & 25.00 & 50.00 & $(10 \mu \mathrm{g} / \mathrm{ml})$ & MIC & MBC \\
Escherichia coli & 20 & 25 & 30 & 35 & 40 & 6.25 & 12.50 \\
Salmonella typhi & - & 15 & 17 & 20 & 35 & 12.5 & 25 \\
\hline
\end{tabular}

$\beta$-Sitosterol is a natural micronutrient found in the cells membranes of all oil producing plants, fruit, vegetables, grains, seeds and trees (Sen et al., 2012).

It is commercially available in preparative amounts only as mixtures with other phytosterols typically stigmasterol and campesterol (Hang and Dussault 2010). $\beta$-Sitosterol has been proven to be a safe, nontoxic, effective nutritional supplement and has amazing potential health benefits in many diverse applications including antibacterial activity (Sen et al., 2012). The antimicrobial activity (inhibitory test) of the isolated compound represented by diameter of zone of inhibition ranged between $20-35 \mathrm{~mm}$ against S. typhii and E.coli at varying concentrations (Table 2). This may be due to the fact that terpenes exhibit antimicrobial activity by complexing proteins such as adhesins, substrates and cell membrane proteins, hence inactivating microbial adhesion which is the first step in establishment of infections, and also causing membrane disruption (Cowan, 1999; Okuda, 2005 and Gopalakrishnakone, 2008). This could justify the used of this plant in the treatment of infectious diseases such as; sore throats, coughs, urinary infections, digestive disorders, skin disorders, arthritis, and to expel tapeworm. The highest sensitivity was recorded in $E$. coli and at inhibition zone of $35 \mathrm{~mm}$ and MIC of $6.25 \mu \mathrm{g} / \mathrm{ml}$ (Table 2) by the isolated sitosterol.

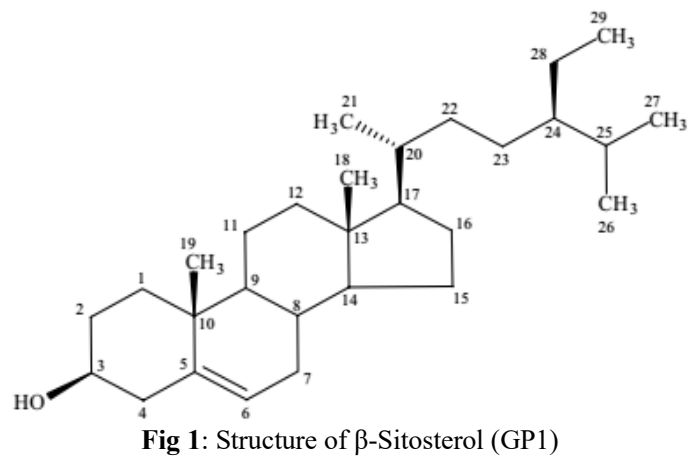

In conclusion, $\beta$-sitosterol was isolated from the stem bark of P.granatum. The significant antibacterial activity of $P$. granatum against $S$. typhi and E. coli could justify the use of the plant in traditional medicine for the treatment of infections, where sitosterol can be used as the antimicrobial agent.

\section{REFERENCES}

Bobblt, JM, 1963. Thin Layer Chromatography. Chapman and Hall Ltd, London: 94.

Cowan, MM. (1999). Plant products as antimicrobial agents. Clinical microbiology reviews, 12(4): 564-582

Edward, A 2001. Pathogenesis Justiciaadhatoda. New, Old and Forgotten Remedies, pp: 210-220.

Hang, J; Dussault, P, (2010) A concise synthesis of $\beta$ sitosterol and other phytosterols. Steroids 75(12):879-883

NCCLS, 2002. Performance standard for antimicrobial susceptibility testing, $12^{\text {th }}$ informational supplements.

NCCLS document M100-512. Wayne, P.A: National Commettee For Chemical Laboratory Standards. Pp 234

Ododo MM; Choudhury, MK; Dekebo, AH (2016) Structure elucidation of $\beta$-sitosterol with antibacterial activity from the root bark of Malvaparviflora, Springer Plus 5:1210

Okuda T (2005).Systematics and health effects of chemically distinct tannins in medicinal plants. $J$. Phytochem. 66:2012-2031.

Patrick, GL (2005). An introduction to medicinal chemistry.( $3^{\text {rd }}$ Ed).Oxford University Press Inc., New York. 161-181

Patra, A; Jha, S; Murthy, PN; Manik Sharone A (2010) Isolation and characterization of stigmast-5-en$3 \beta$-ol ( $\beta$-sitosterol) from the leaves of Hygrophilaspinosa T. Anders. Int J PharmaSci Res 1(2):95-100.

Pateh, UU; Haruna, AK; Garba, M; Iliya, I; Sule, IM; Abubakar, MS; Ambi, AA (2009) Isolation of stigmasterol, $\quad \beta$-sitosterol and 2hydroxyhexadecanoic acid methyl ester from the rhizomes of StylochitonlancifoliusPyer and Kotchy (Araceae). Nig. J Pharm Sci. 8(1):19-25 
Samy, RP; Gopalakrishnakone, P. (2008). Review: Therapeutic potential of plants asanti-microbials for drug discovery. J. Environ.-Based Compl and Alternative med.e:doi:10.1093/ecam/nen036.

Sen, A; Dhavan, P; Shukla, KK; Singh, S; Tejovathi; G (2012) Analysis of IR, NMR and antimicrobial activity of $\beta$-sitosterol isolated from Momordicacharantia. Sci. Secure J Biotech 1(1):9-13

Shrikumar, S; Ravi, TK (2007) Approaches towards development and promotion of herbal spices and flavouring agents. Global J. Pure Appl. Sci.7 (3): 455-459.

Shinawie, A (2002).Wounder drugs of medicinal plants. Ethnobotony. ISSN 025-039X Vol 29, Issue 1.
Singh R. P and Padmavathi, (2000). Modulatory influence of Adhatodavasica leaf extract on the Enzymes of xenobiotic metabolism, antioxidant status and lipid per oxidation in mice. Mol. Cell Biochem. 213 (1-2): 99-109

Sofowora, L.A (1993) Medicinal plants and traditional medicine in Africa. Spectrum Books Limited. Ibadan Nigeria. pp 130

Srivastave, VK; Srivastave, KK. (1987). An introduction to chromatography. Theor. Prac., (5): $50-52$.

Tijjani, A; Haruna, A; Jacob AG. (2017). Bactericidal Studies of Saponins from the stembarkofAdeniumobesum (Forssk) Roem and Schult. Bayero J. Pure and App. Sci., 10(1): 247250 